\title{
Performance analyses on fluidized bed dryer integrated biomass furnace with and without air preheater for paddy drying
}

M.Yahya, Hendriwan Fahmi, Syafrul Hadi, Edison

Fakultas Teknologi Industri, Institut Teknologi Padang, Indonesia

\begin{tabular}{l}
\hline Article Info \\
\hline Article history: \\
Received Dec 12, 2018 \\
Revised Mar 3, 2019 \\
Accepted Mar 18, 2019 \\
\hline
\end{tabular}

Keywords:

Air main heater

Air preheater

Fluidized bed dryer

Paddy

Performance

\begin{abstract}
The performance of a fluidized bed dryer integrated biomass furnace with air preheater (FBD with $\mathrm{APH}$ ) and a fluidized bed dryer integrated biomass furnace without air preheater (FBD without APH) for drying of paddy have been evaluated. The FBD with APH and FBD without APH decreased the moisture of paddy from $24 \%$ (wet basis) to $14 \%$ (wet basis) within 43 and 47 minutes with average temperatures and relative humidities of $59.58 \mathrm{oC}$ and $59.14 \mathrm{oC}$, and $18.81 \%$ and $18.68 \%$, respectively. The drying rate of paddy varied in the range of $0.11 \mathrm{~kg} / \mathrm{min}-0.32 \mathrm{~kg} / \mathrm{min}$ and $0.10 \mathrm{~kg} / \mathrm{min}-0.30 \mathrm{~kg} / \mathrm{min}$ for FBD with APH and FBD without APH, with average values of $0.18 \mathrm{~kg} / \mathrm{min}$ and $0.17 \mathrm{~kg} / \mathrm{min}$, respectively. The minimum, maximum, and average value specific moisture evaporation rate (SMER) was $0.20 \mathrm{~kg} / \mathrm{kWh}$, $0.57 \mathrm{~kg} / \mathrm{kWh}$, and $0.31 \mathrm{~kg} / \mathrm{kWh}$, respectively for FBD with APH, as well as $0.149 \mathrm{~kg} / \mathrm{kWh}, 0.448 \mathrm{~kg} / \mathrm{kWh}$, and $0.252 \mathrm{~kg} / \mathrm{kWh}$, respectively, for FBD without APH. The specific energy consumption (SEC), the specific electrical energy consumption (SEEC), and the specific thermal energy consumption (STEC) were varied from $1.749 \mathrm{kWh} / \mathrm{kg}$ to $5.076 \mathrm{kWh} / \mathrm{kg}$, $0.090 \mathrm{kWh} / \mathrm{kg}$ to $2.872 \mathrm{kWh} / \mathrm{kg}$, and $0.760 \mathrm{kWh} / \mathrm{kg}$ to $2.204 \mathrm{kWh} / \mathrm{kg}$, with average values of $3.528 \mathrm{kWh} / \mathrm{kg}, 1.96 \mathrm{kWh} / \mathrm{kg}$, and $1.532 \mathrm{kWh} / \mathrm{kg}$, respectively for FBD with $\mathrm{APH}$, as well as from $2.234 \mathrm{kWh} / \mathrm{kg}$ to 6.702 $\mathrm{kWh} / \mathrm{kg}, 1.056 \mathrm{kWh} / \mathrm{kg}$ to $3.167 \mathrm{kWh} / \mathrm{kg}$, and $1.179 \mathrm{kWh} / \mathrm{kg}$ to 3.536 $\mathrm{kWh} / \mathrm{kg}$, with average values of $4.391 \mathrm{kWh} / \mathrm{kg}, 2.075 \mathrm{kWh} / \mathrm{kg}$, and 2.316 $\mathrm{kWh} / \mathrm{kg}$, respectively, for FBD without APH. The thermal efficiencies of the FBD with APH and FBD without APH were varied between $12.4 \%$ and $37.93 \%$, and $9.78 \%$ and $29.82 \%$, resvectively, with average values of $20.78 \%$ and $16.61 \%$. The thermal efficiency of FBD with APH was higher compared to FBD without APH.
\end{abstract}

Copyright (c) 2019 Institute of Advanced Engineering and Science. All rights reserved.

\section{Corresponding Author:}

M. Yahya, Fakultas Teknologi Industri, Institut Teknologi Padang, Indonesia, 25146.

Email: yahya_err@yahoo.com

\section{INTRODUCTION}

Drying is one of the oldest methods for preservation of food or biologically active products such as paddy, fish, and chili. Drying is primarily performed to decrease the moisture content of food or biologically active products to a save level for storage [1]. The open sun drying and mechanical dryer are commonly used for drying of food or biologically active products. The open sun drying is very simple and cheap but low quality products and low drying rates. The mechanical dryer has the disadvantage that energy is used to heat the drying air for drying operation still depends on fossil fuels and consumes much energy, while the fossil fuels are expensive and steadily increasing, as well as their sources are limited [2]. Many studies used a solar 
dryer integrated with biomass furnace (biomass burner or stove) to solve the problems of open sun drying and mechanical drying.

A solar dryer integrated with biomass furnace is used as an alternative to open sun drying and mechanical drying because it result high quality products, short drying time, and also the solar and biomass energies are renewable and abundant [3]. A solar tunnel greenhouse dryer coupled with biomass backup heater for drying of coconuts has been studied experimentally by Arun et al. [4]. The dimension of the dryer is $4 \mathrm{~m}(\mathrm{~W}) \times 10 \mathrm{~m}(\mathrm{~L}) \times 3 \mathrm{~m}(\mathrm{H})$. They found that the dryer reduced the moisture content of coconut from $53.84 \%$ wet basis to $7.003 \%$ wet basis within 44 hours.

Yahya [5] has investigated experimentally a solar-assisted heat pump dryer integrated with biomass furnace by using cabinet type of drying chamber for drying red chillies a capacity of $22 \mathrm{~kg}$. The researcher reported that the dryer able to reduce the moisture content of red chillies from 4.26 dry basis to 0.08 dry basis within 11 hours at an air mass flow rate of $0.124 \mathrm{~kg} / \mathrm{s}$, with the averages drying chamber temperature and drying chamber relative humidity of $70.5^{\circ} \mathrm{C}$ and $10.1 \%$, respectively. The thermal efficiency of the dryer was estimated in average of about $9.03 \%$. Meanwhile, the averages contribution of heat energy by the collector, condenser and biomass furnace were obtained of about $14.74 \%, 47.39 \%$ and $37.87 \%$, respectively.

A solar-assisted fluidized bed dryer integrated with biomass furnace for drying of paddy was designed, constructed, and evaluated by Yahya et al. [6]. The drying system reduced the mass of the paddy from $12 \mathrm{~kg}$ to $11.43 \mathrm{~kg}$ with mass flow rate of $0.125 \mathrm{~kg} / \mathrm{s}$. Moisture content was dried off the paddy by $14 \%$ from $20 \%$ (wet basis) in $796 \mathrm{~s}$ with average temperature of $78 \mathrm{oC}$. The average thermal efficiency is $16.28 \%$ for average air temperature drying of $78 \mathrm{oC}$, respectively. The average solar fraction (SF) is $15.01 \%$ for average drying temperature of $78 \mathrm{oC}$, respectively. Whereas, the average biomass fraction (BF) is $42.22 \%$ for average drying temperature of $78 \mathrm{oC}$, respectively.

Hamdani et al. [7] have fabricated and tested a hybrid solar-biomass dryer for drying of fish. The dryer consists of a drying chamber of length $260 \mathrm{~cm}$ and width of $80 \mathrm{~cm}$, with glass as a cover. A cross flow type heat exchanger for an air heater that utilizes biomass fuel also mounted to the dryer. The dryer reduce the mass of fish from $25 \mathrm{~kg}$ to $12.3 \mathrm{~kg}$ with moisture content of $12 \%$ within 15 hours. In the beginning, drying was conducted using solar energy, from 09:00 to 16:00, and continued with hot-air produced from biomass combustion from 16:00-06:00 and maintained at $40-50^{\circ} \mathrm{C}$. However, commonly the flue gas temperature leaving the chimney of biomass furnace (biomass burner or stove) is high, which causes great waste thermal loss and fuel consumption rate of drying system, and also this can be influences the thermal efficiency of drying system.

To minimize thermal loss from chimney of biomass furnace, decrease the fuel consumption rate and increase the thermal efficiency of drying system, Tadahmun et al. [8] have used a sub dryer as heat recovery to a hybrid solar thermal drying system for drying of red chili. The drying system consists of solar air heater, drying chamber, dryer chimney, thermal back-up unit, recovery dryer, and flue gas chimney. They found that the overall drying efficiency of the hybrid solar thermal drying system with and without recovery dryer were $13 \%$ and $10.3 \%$, respectively. However, no study has been reported yet on the performance of the drying system integrated biomass furnace using two air heaters namely air preheater and air main heater. Therefore, the objective of this study is to compare the experimental performance of FBD with and without air preheater (APH) for drying of paddy.

\section{RESEARCH METHOD}

\subsection{Experimental set-up}

A fluidised bed dryer integrated with two stage biomass furnace was fabricated and tested at the Institut Teknologi Padang, West Sumatra, Indonesia. The drying system consisted of two stage biomass furnace, fluidised bed (drying chamber), cyclone and blower, as shown in Figure 1. The biomass furnace comprised several main parts, such as the heat exchanger, combustion chamber, chimney and blower. The heat exchanger has two stage air heater namely first stage is air main heater (AMH) and second stage is air preheater (APH). The air main heater and air preheater both has 14-unit heat exchanger pipes were composed of mild steel with diameter of 2.5 inc. The wall of the combustion chamber used brick, cement and steel plate materials. The fluidised bed consisted of the drying chamber, air flow distribution and inlet and outlet of paddy. The front part of the drying chamber was covered with clear glass with a thickness of $5 \mathrm{~mm}$, and the sides and back were covered with $3 \mathrm{~mm}$-thick aluminium plate. The air distributor used wire aluminium gauze. The cyclone was covered with $3 \mathrm{~mm}$-thick aluminium plate. The drying air was circulated using centrifugal blower with $3.7 \mathrm{~kW}$.

Int J Pow Elec \& Dri Syst, Vol. 10, No. 3, Sep 2019 : 1555 - 1563 


\subsection{Experimental procedure}

Experiments were performed at Institut Teknologi Padang, West Sumatra, Indonesia. Farmers bought freshly harvested paddy in Padang, and approximately $14 \mathrm{~kg}$ was placed into the drying chamber for the drying process. The biomass fuel used was coconut shell charcoal. The drying experiments were conducted to evaluate the performance of fluidized bed dryer integrated with two stage biomass furnace for drying of paddy. The air temperatures at the inlet and outlet of the air main heater and air preheater of biomass furnace, drying chamber, and also, the combustion air temperature and flue gas temperature leaving of chimney of biomass furnace during the operation of the drying system were measured by using T-type copper-constantan thermocouples with an accuracy of $\pm 0.1^{\circ} \mathrm{C}$ and operating temperature ranging from -200 ${ }^{\circ} \mathrm{C}$ to $400{ }^{\circ} \mathrm{C}$ and operating relative humidity ranging from $0 \%$ to $100 \%$. Air velocity was measured with a 0 $30 \mathrm{~ms}-1$ range by using a HT383 anemometer, with an accuracy of $\pm 0.2 \mathrm{~ms}-1$ and operation temperature ranging from $-10{ }^{\circ} \mathrm{C}$ to $45{ }^{\circ} \mathrm{C}$. The air temperatures were recorded by using an $\mathrm{AH} 4000$ data logger with a reading accuracy of $\pm 0.1{ }^{\circ} \mathrm{C}$. The mass change of the pady was measured within a $0-15 \mathrm{~kg}$ range by using a TKB- 0.15 weighing scale with an accuracy of $\pm 0.05 \mathrm{~kg}$. Paddy mass change was weighed, and temperature was measured every $5 \mathrm{~min}$. The drying experiments were performed to evaluate the dryer performance under two different operating modes: FBD with APH operation mode, and FBD without APH operation mode. Air preheater was not used for FBD without APH operation mode, as shown in Figure 2. Air preheater was employed for FBD with APH operation mode, as shown in Figure 3.

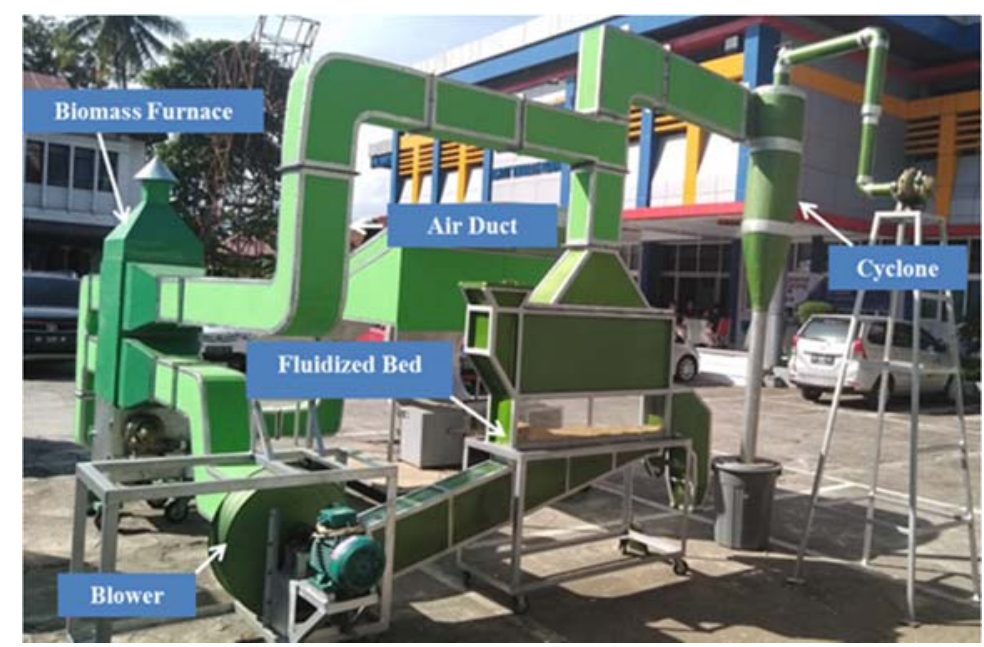

Figure 1. Photograph of fluidized bed dryer integrated biomass furnace

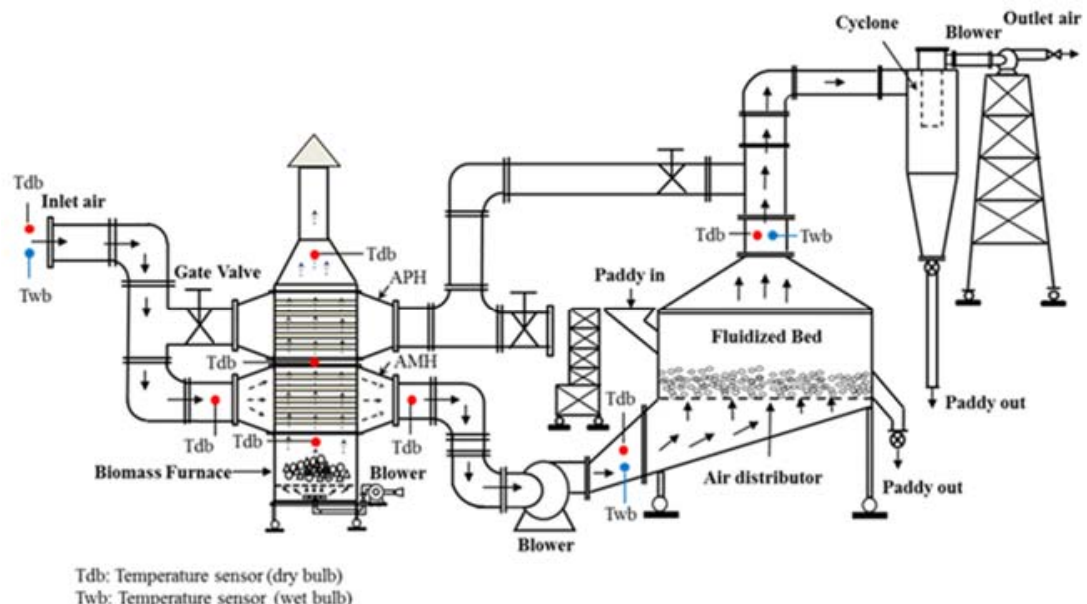

Figure 2. Schematic diagram of FBD without APH operation mode.

Performance analyses on fluidized bed dryer integrated biomass furnace with and without air ... (M.Yahya) 


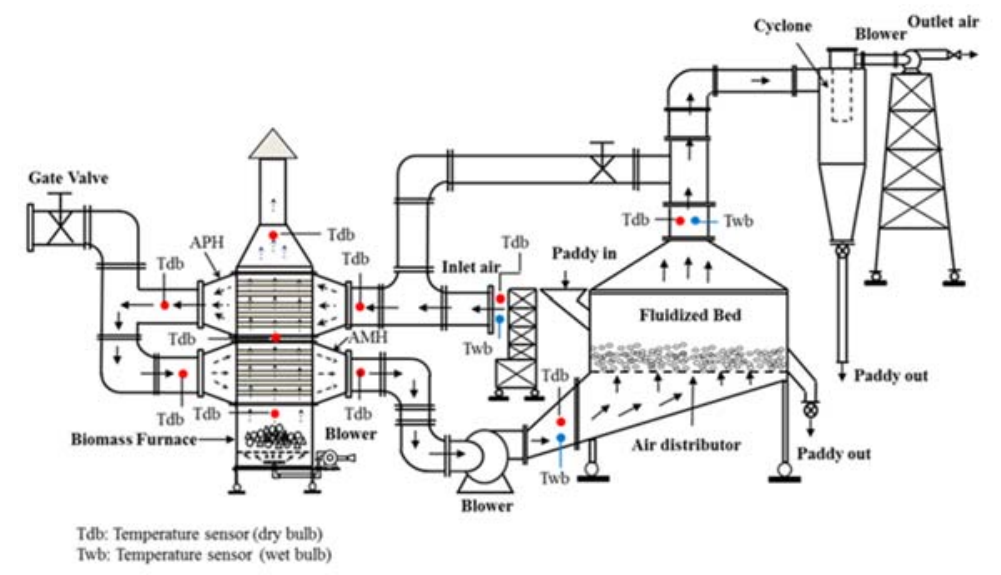

Figure 3. Schematic diagram of FBD with APH operation mode

\subsection{Performance Analyses}

The moisture content (wet basis), the drying rate, the specific moisture evaporation rate (SMER), the specific energy consumption (SEC), the specific thermal energy consumption (STEC), the specific electrical energy consumption (SEEC), and the thermal efficiency of drying system were calculated using equaitions in Table $1[9]-[15]$.

\begin{tabular}{ll}
\hline Indications of performance & Performance equation \\
\hline The moisture content (wet basis) & $\mathrm{M}_{\mathrm{wb}}=\frac{\mathrm{m}_{\text {wetpd }}-\mathrm{m}_{\mathrm{dpd}}}{\mathrm{m}_{\mathrm{wetpd}}}$ \\
The drying rate & $\dot{\mathrm{m}}_{\mathrm{water}}=\frac{\mathrm{m}_{\mathrm{water}}}{\dot{t}}$ \\
The specific moisture evaporation rate & $\mathrm{SMER}=\frac{\dot{\dot{\mathrm{m}}_{\mathrm{water}}}}{\mathrm{E}_{\mathrm{bmf}}+\mathrm{E}_{\mathrm{bl}}}$ \\
The specific energy consumption & $\mathrm{SEC}=\frac{\mathrm{E}_{\mathrm{bmf}}+\mathrm{E}_{\mathrm{bl}}}{\dot{\mathrm{m}}_{\mathrm{water}}}$ \\
The specific thermal energy consumption & $\mathrm{STEC}=\frac{\mathrm{E}_{\mathrm{bmf}}}{\dot{\mathrm{m}}_{\mathrm{water}}}$ \\
The specific electrical energy consumption & $\mathrm{SEEC}=\frac{\mathrm{E}_{\mathrm{bl}}}{\dot{\mathrm{m}}_{\mathrm{water}}}$ \\
The thermal efficiency of drying system & $\eta_{\mathrm{th}}=\frac{\dot{\mathrm{m}}_{\mathrm{water}} \mathrm{H}_{\mathrm{fg}}}{\mathrm{E}_{\mathrm{bmf}}+\mathrm{E}_{\mathrm{bl}}}$
\end{tabular}

\section{RESULTS AND ANALYSIS}

The variation of the temperature at inlet and outlet of the air main heater of biomass furnace of FBD without APH with drying time is shown in Figure 4. These temperatures were varied between $39.12{ }^{\circ} \mathrm{C}$ and $41.90{ }^{\circ} \mathrm{C}$, and $59.60{ }^{\circ} \mathrm{C}$ and $62.90^{\circ} \mathrm{C}$, with average values of $40.05^{\circ} \mathrm{C}$ and $60.93^{\circ} \mathrm{C}$, respectively.

The variation of the temperature at inlet and outlet of the air preheater and air main heater of biomass furnace of FBD with APH versus drying time is displayed in Figure 5. These temperatures were observed in the range of $32.36^{\circ} \mathrm{C}-42.20^{\circ} \mathrm{C}$ and $45.47{ }^{\circ} \mathrm{C}-51.20^{\circ} \mathrm{C}$, and $44.46{ }^{\circ} \mathrm{C}-49.80^{\circ} \mathrm{C}$ and $61.10{ }^{\circ} \mathrm{C}-$ $63.50^{\circ} \mathrm{C}$, with average values of $38.28^{\circ} \mathrm{C}$ and $48.29^{\circ} \mathrm{C}$, and $47.35^{\circ} \mathrm{C}$ and $61.98^{\circ} \mathrm{C}$, respectively. 


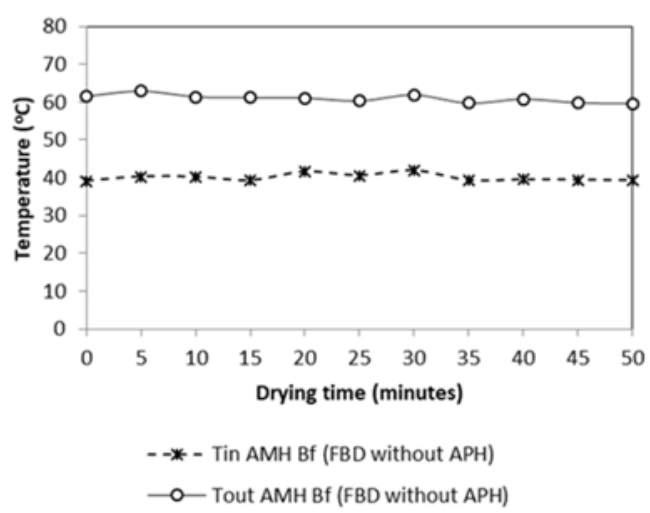

Figure 4. Variation in temperature with drying time for FBD without APH

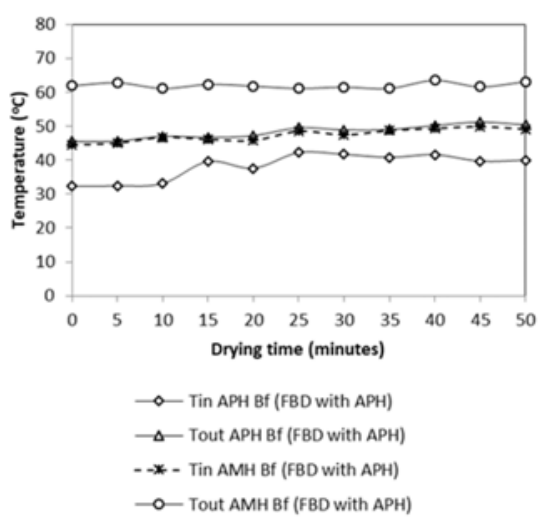

Figure 5. Variation in temperature with drying time for FBD with APH

The variation of the combustion air temperature and the flue gas temperature living of biomass furnace for FBD with APH and FBD without APH versus drying time is depicted in Figure 6. The combustion air temperature and the flue gas temperature living of chimney of biomass furnace for FBD with APH and FBD without APH varied in the range of $272.3^{\circ} \mathrm{C}-377.3^{\circ} \mathrm{C}$ and $121.1^{\circ} \mathrm{C}-168.3{ }^{\circ} \mathrm{C}$, and $285.2^{\circ} \mathrm{C}-$ $355.8^{\circ} \mathrm{C}$ and $172.2{ }^{\circ} \mathrm{C}-230.6{ }^{\circ} \mathrm{C}$, with average values of $313.2{ }^{\circ} \mathrm{C}$ and $150.9{ }^{\circ} \mathrm{C}$, and $325.54{ }^{\circ} \mathrm{C}$ and 193.6 ${ }^{\circ} \mathrm{C}$, respectively.

The variation of temperature and relative humidity with drying time are demonstrated in Figure 7. The temperature and the relative humidity at the inlet and outlet of the drying chamber were observed in the range of $58.02{ }^{\circ} \mathrm{C}-60.80{ }^{\circ} \mathrm{C}$ and $17.30 \%-21.06 \%$, and $36.42{ }^{\circ} \mathrm{C}-49.0{ }^{\circ} \mathrm{C}$ and $18.30 \%-48.42 \%$, with average values of $59.58{ }^{\circ} \mathrm{C}$ and $18.81 \%$, and $43.01{ }^{\circ} \mathrm{C}$, and $26.93 \%$, respectively FBD with APH, as well as 58.40 ${ }^{\circ} \mathrm{C}-60.24{ }^{\circ} \mathrm{C}$ and $16.20 \%-20.10 \%$, and $37.09{ }^{\circ} \mathrm{C}-50.02{ }^{\circ} \mathrm{C}$ and $22.13 \%-49.03 \%$, with average values of 59.14 ${ }^{\circ} \mathrm{C}$ and $18.68 \%$, and $42.73{ }^{\circ} \mathrm{C}$ and $29.61 \%$, respectively, for FBD without APH.

The variation of moisture content of paddy and drying rate with drying time for FBD with APH and FBD without APH are shown in Figure 8. The moisture content of paddy in the FBD with APH and FBD without APH were reduced from $24 \%$ wet basis to $14 \%$ wet basis within 43 and 47 minutes, respectively. The drying rate varied from $0.11 \mathrm{~kg} / \mathrm{min}$ to $0.32 \mathrm{~kg} / \mathrm{min}$ for FBD with APH and from $0.10 \mathrm{~kg} / \mathrm{min}$ to 0.30 $\mathrm{kg} / \mathrm{min}$ for FBD without APH, with an average of $0.18 \mathrm{~kg} / \mathrm{min}$ and $0.17 \mathrm{~kg} / \mathrm{min}$, respectively.

The variation of SMER with drying time is illustrated in Figure 9. SMER varied from $0.20 \mathrm{~kg} / \mathrm{kWh}$ to $0.57 \mathrm{~kg} / \mathrm{kWh}$ for FBD with APH and from $0.149 \mathrm{~kg} / \mathrm{kW}$ h to $0.448 \mathrm{~kg} / \mathrm{kWh}$ for FBD without APH, with average values of $0.31 \mathrm{~kg} / \mathrm{kW} \mathrm{h}$ and $0.252 \mathrm{~kg} / \mathrm{kW} \mathrm{h}$, respectively.

The variations of SEC, SEEC and STEC with drying time are shown in Figure 10. SEC, SEEC and STEC varied in the range of $1.749 \mathrm{kWh} / \mathrm{kg}-5.076 \mathrm{kWh} / \mathrm{kg}, 0.90 \mathrm{kWh} / \mathrm{kg}-2.872 \mathrm{kWh} / \mathrm{kg}$ and $0.76 \mathrm{kWh} / \mathrm{kg}$ $-2.204 \mathrm{kWh} / \mathrm{kg}$, with average values of $3.528,1.996$ and $1.532 \mathrm{kWh} / \mathrm{kg}$, respectively For FBD with APH, as well as $2.234 \mathrm{kWh} / \mathrm{kg}-6.702 \mathrm{kWh} / \mathrm{kg}, 1.056 \mathrm{kWh} / \mathrm{kg}-3.167 \mathrm{kWh} / \mathrm{kg}$ and $1.179 \mathrm{kWh} / \mathrm{kg}-3.536 \mathrm{kWh} / \mathrm{kg}$, with average values of 4.391, 2.075 and $2.316 \mathrm{kWh} / \mathrm{kg}$, respectively, for FBD Without APH, as well as, as shown in Figure 10, the SEC, SEEC and STEC increased with an increase in drying time.

The variation of thermal efficiencies of drying system are depicted in Figure 11. The thermal efficiencies of drying system of FBD with APH and FBD without APH were varied from $12.92 \%$ to $37.93 \%$ for FBD with $\mathrm{APH}$ and from $9.78 \%$ to $29.826 \%$ for FBD without $\mathrm{APH}$, with average values of $20.78 \%$ and $16.61 \%$, respectively. 


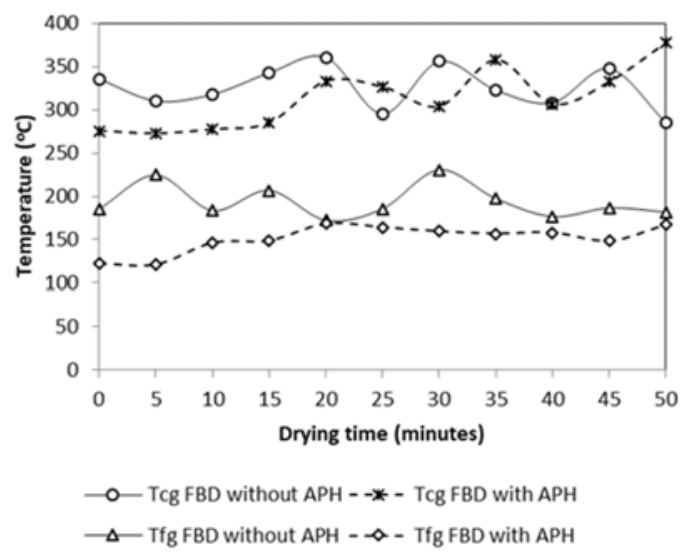

Figure 6. Variation in temperature of combustion and flue gas with drying time for FBD with APH and FBD without APH

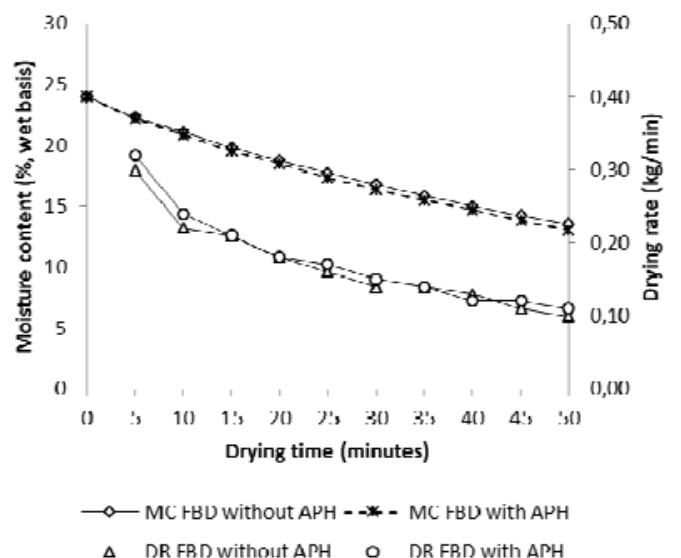

Figure 8. Variation in moisture content and drying rate with drying time

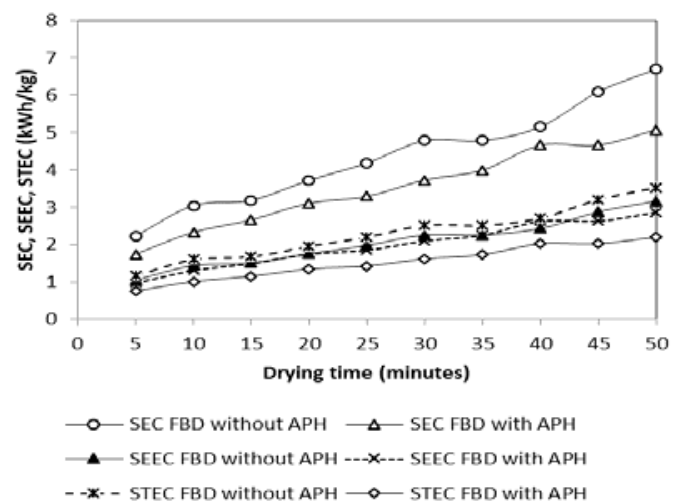

Figure 10. Variation in SEC, SEEC, and STEC with drying time

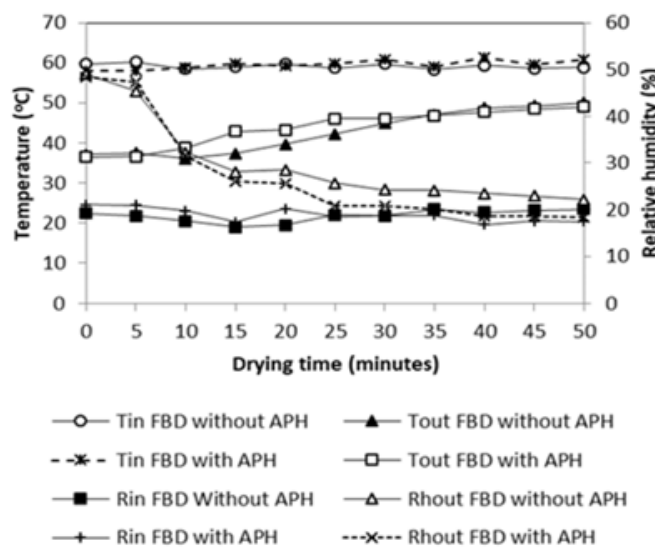

Figure 7. Variation in temperature and relative humidity with drying time

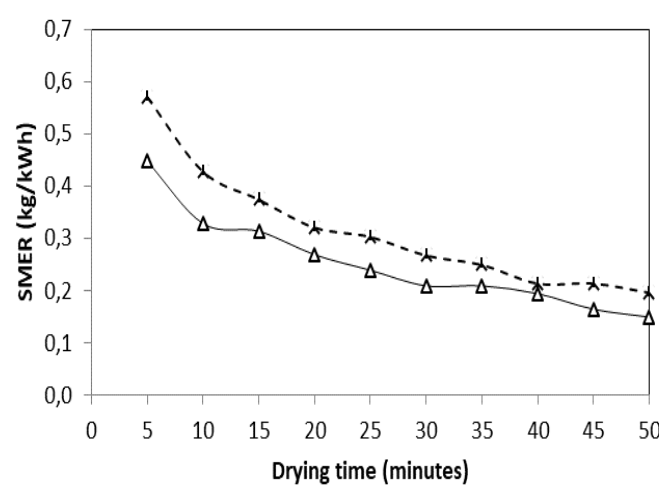

$\triangle-$ SMER FBD without APH $\quad--\star-$ SMER FBD with APH

Figure 9. Variation in SMER with drying time

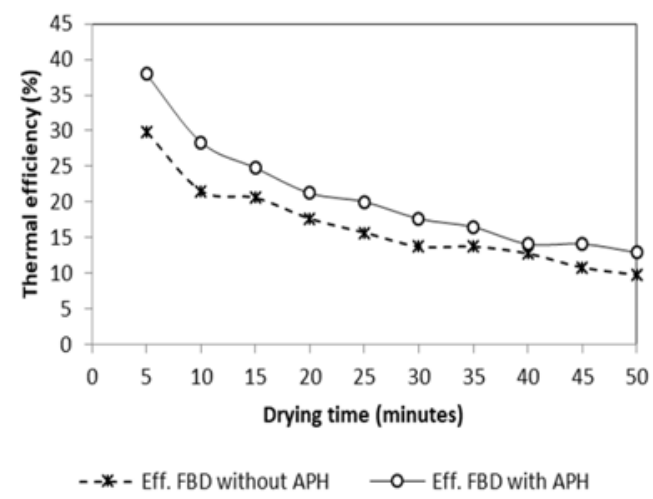

Figure 11. Variation in thermal efficiency with drying time 


\section{CONCLUSION}

In this study, a fluidized bed dryer integrated biomass furnace was fabricated and tested for drying of paddy. The experiment results indicated that:

The coconut shell charcoal (biomass fuel) is used as heat energy source for fluidized bed dryers. The FBD with APH and FBD without APH decreased the moisture content of paddy from 24\% wet basis to $14 \%$ wet basis within 43 and 47 minutes with average temperatures and relative humidities of 59.58 oC and 59.14 $\mathrm{oC}$, and $18.81 \%$ and $18.68 \%$, respectively. The average drying rate of paddy for FBD with APH and FBD without APH were $0.18 \mathrm{~kg} / \mathrm{min}$ and $0.17 \mathrm{~kg} / \mathrm{min}$, respectively. The average specific moisture evaporation rate (SMER) for FBD with APH and FBD without APH were $0.31 \mathrm{~kg} / \mathrm{kWh}$ and $0.252 \mathrm{~kg} / \mathrm{kWh}$, respectively. The average specific energy consumption (SEC) for FBD with APH and FBD without APH were $3.528 \mathrm{kWh} / \mathrm{kg}$ and $4.391 \mathrm{kWh} / \mathrm{kg}$, respectively. The average specific electrical energy consumption (SEEC) for FBD with APH and FBD without APH were $1.96 \mathrm{kWh} / \mathrm{kg}$ and $2.075 \mathrm{kWh} / \mathrm{kg}$, respectively. The avearge specific thermal energy consumption (STEC) for FBD with APH and FBD without APH were $1.532 \mathrm{kWh} / \mathrm{kg}$ and $2.316 \mathrm{kWh} / \mathrm{kg}$, respectively. The average thermal efficiencies for FBD without APH and FBD with APH were $20.78 \%$ and $16.61 \%$, respectively. The FBD with APH is better than FBD without APH because its thermal efficiency is higher than FBD without APH.

\section{Nomenclature}

$\begin{array}{ll}\mathrm{E}_{\mathrm{bl}} & \text { electrical energy consumed by blower }(\mathrm{W}) \\ \mathrm{E}_{\mathrm{bmf}} & \text { heat energy generated by the combustion of biomass fuel }(\mathrm{W}) \\ \mathrm{H}_{\mathrm{fg}} & \text { laten heat of vaporization of water }(\mathrm{J} / \mathrm{kg}) \\ \mathrm{M}_{\mathrm{wb}} & \text { moisture content wet basis }(\%) \\ \mathrm{m}_{\mathrm{dpd}} & \text { mass of bone dry of paddy }(\mathrm{kg}) \\ \mathrm{m}_{\mathrm{wetpd}} & \text { mass of wet paddy (kg) } \\ \dot{\mathrm{m}}_{\text {water }} & \text { drying rate (kg/minutes) } \\ \mathrm{m}_{\text {water }} & \text { mass of water evaporated }(\mathrm{kg}) \\ \mathrm{SEC} & \text { specific energy consumption }(\mathrm{kWh} / \mathrm{kg}) \\ \mathrm{STEC} & \text { specific thermal energy consumption }(\mathrm{kWh} / \mathrm{kg}) \\ \mathrm{SEEC} & \text { specific electrical energy consumption }(\mathrm{kWh} / \mathrm{kg}) \\ \mathrm{SMER} & \text { specific moisture evaporation rate }(\mathrm{kg} / \mathrm{kWh}) \\ \mathrm{t} & \text { drying time (minutes) } \\ \eta_{\text {th }} & \text { thermal efficiency of the drying system }(\%)\end{array}$

\section{ACKNOWLEDGEMENTS}

The authors would like to thank the Ministry of Research, Technology and Higher Education of the Republic of Indonesia for its research funding through the Penelitian Terapan Unggulan Perguruan Tinggi (PTUPT) Research Grant scheme.

\section{REFERENCES}

[1] M. Yahya, A. Fudholi, H. Hafizh, K. Sopian, "Comparison of solar dryer and solar-assisted heat pump dryer for cassava,” Solar Energy, vol. 136, pp. 606-613, 2016.

[2] A. Fudholi, M. Y. Othman, M. H. Ruslan, K. Sopian, "Drying of Malaysian Capsicum annuum L. (red chili) dried by open and solar drying," International Journal of Photoenergy, pp. 1-9, 2013.

[3] M.Yahya, H. Fahmi, A. Fudholi, K. Sopian, "Performance and economic analyses on solar-assisted heat pump fluidised bed dryer integrated with biomass furnace for rice drying," Solar Energy, vol. 174, pp. 1058-1067, 2018. 
[4] S. Arun, S. Shankar Balaji, Selvan, " Experimental studies on drying characteristics of coconut in a solar tunnel greenhouse dryer coupled with biomass backup heater," International Journal of Innovative Technology and Exploring Engineering, vol.4, no.5, pp. 56-60, 2014.

[5] M. Yahya, "Design and performance evaluation of a solar assisted heat pump dryer integrated with biomass furnace for red chilli," International Journal of Photoenergy, pp.1-14, 2016.

[6] M. Yahya, A. Fudholi, K. Sopian, "Energy and exergy analyses of solar-assisted fluidized bed drying integrated with biomass furnace," Renewable Energy, vol.105, pp. 22-29, 2017.

[7] Hamdani, T.A. Rizal, M. Zulfri, "Fabrication and testing of hybrid solar-biomass dryer for drying fish," Case Studies in Thermal Engineering, vol, pp. Xxx-xxx, 2018.

[8] T.A. Yassen, H.H. Al-Kayiem, "Experimental investigation and evaluation of hybrid solar/thermal dryer combined with supplementary recovery dryer," Solar Energy, vol.134, pp.284-293, 2016.

[9] I. Ceylan, M. Aktas, "Modeling of a hazelnut dryer assisted heat pump by using artificial neural networks," Applied Energy, pp. 1-13, 2008.

[10] A. Fadhel, S. Kooli, A. Farhat, A. Belghith, "Experimental study of the drying of hot red pepper in the open air, under greenhouse and in a solar drier," International Journal of Renewable Energy and Biofuels, pp. 1-14, 2014.

[11] I. Ceylan, M. Aktas, H. Dogan, "Energy and exergy analysis of timber dryer assisted heat pump," Applied Thermal Engineering, vol. 27, pp. 216-222, 2007.

[12] A. Fudholi, K. Sopian, M. Y. Othman, M. H. Ruslan, "Energy and exergy analyses of solar drying system of red seaweed," Energy and Building, vol. 68, pp. 121-129, 2014.

[13] M.S.N. Sarker, M.N. Ibrahim, N. Ab. Aziz, M.S. Punan, "Application of simulation in determining suitable operating parameters for industrial scale fluidized bed dryer during drying of high impurity moist paddy," Journal of Stored Products Research, pp. 1-9, 2014.

[14] M. N. Ibrahim, M.S.H. Sarker, AB. Aziz N , M. Salleh, "Drying performance and overall energy requisite of industrial inclined bed paddy drying in Malaysia," Journal of Engineering Science and Technology, vol. 9, no. 3, pp. 398-409, 2014.

[15] J. Banout, P. Ehl, J. Havlik, B. Lojka, Z. Polesny, V. Verner, "Design and performance evaluation of a Double-pass solar drier for drying of red chilli (Capsicum annum L.)," Solar Energy, vol. 85, no. 3, pp. 506-515, 2011.

Int J Pow Elec \& Dri Syst, Vol. 10, No. 3, Sep 2019 : 1555 - 1563 


\section{BIOGRAPHIES OF AUTHORS}

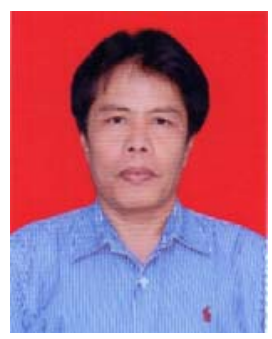

Dr. M.Yahya, M.Sc presently working as a Professor in Department of Mechanical Engineering, Institut Teknologi Padang, Indonesia. He recieved B.Eng degree in mechanical engineering from Universitas Bung Hatta, Padang, Indonesia, 1n 1989. He recieved M.Sc and P.hD degrees both in mechanical engineering from Universiti Kebangsaan Malaysia, in 1996 and 2007, resvectively. His research intereshs are renewable energy, solar thermal system and solar drying system. He served as was a senior research fellow at the Solar Energy Research Institute (SERI), Universiti Kebangsaan Malaysia, for four years (2007-2011). He has published over 75 research papers in journals and conferences. His total citations of 214 by 140 documents and hindex of 10 in Scopus (Author ID: 36983236900). He recieved several awards such as Gold Medal award at International Exhibition of Invention, New Techniques and Products (GenevaSwitzerland) 2005, Gold Medal award at Expo International Invention-Innovation and Technology Exhibition (Kuala Lumpur-Malaysia) 2009, Gold Medal award at Expo International Invention-Innovation Industrial Design Technology (Kuala Lumpur-Malaysia) 2010, and Gold Medal award at International Exposition of Research and Invention (PECIPTA) 2011. He was invited as speaker on workshop of writing scientific papers steps towards successful publish in international journals.

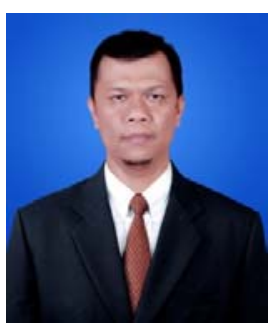

Hendriwan Fahmi, M.Eng received B.Eng degree in mechanical engineering from Sekolah Tinggi Teknik Padang, in 2000. He recieved M. Eng degree in mechanical engineering from Universitas Gadjah Mada, Yogyakarta, Indonesia, in 2004. He has been a lecturer in the Department of Mechanical Engineering, Institut Teknologi Padang, Indonesia. His research intereshs are ceramic and composite, and ceramic engineering.

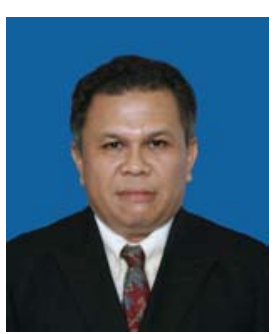

Syafrul Hadi, M.Eng received B.Eng degree in mechanical engineering from Sekolah Tinggi Teknik Padang, in 2000. He recieved M. Eng degree in mechanical engineering from Universitas Gadjah Mada, Yogyakarta, Indonesia, in 2004. He has been a lecturer in the Department of Mechanical Engineering, Institut Teknologi Padang, Indonesia. His research intereshs are applied thermodynamic and heat and mass transfer.

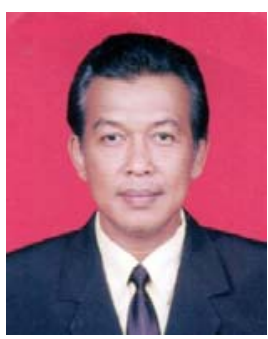

Edison, M. Eng recieved B.Eng degree in mechanical engineering from Universitas Bung Hatta, Padang, Indonesia, 1n 1990. He recieved M. Eng degree in mechanical engineering from Institut Sains dan Teknologi Nasional, Jakarta, Indonesia, in 2012. He has been a lecturer in the Department of Mechanical Engineering, Institut Teknologi Padang, Indonesia. His research intereshs are machinery maintenance and equipment design. 